\title{
病原細菌に対する新しい薬剤標的一二成分情報伝達システム
}

\author{
内海龍太郎, ${ }^{*}, a$ 五十嵐雅之 ${ }^{b}$
}

\section{Two-component Signal Transduction as Attractive Drug Targets in Pathogenic Bacteria}

\author{
Ryutaro Utsumi*,a and Masayuki Igarashi ${ }^{b}$ \\ ${ }^{a}$ Department of Bioscience, Graduate School of Agriculture, Kinki University; 3327-204 \\ Nakamachi, Nara 631-8505, Japan: and ${ }^{b}$ Institute of Microbial Chemistry; \\ 3-14-23 Kamiosaki, Shinagawa-ku, Tokyo 141-0021, Japan.
}

(Received August 30, 2011)

\begin{abstract}
Gene clusters contributing to processes such as cell growth and pathogenicity are often controlled by two-component signal transduction systems (TCSs). TCS consists of a histidine kinase (HK) and a response regulator (RR). TCSs are attractive as drug targets for antimicrobials because many HK and RR genes are coded on the bacterial genome though few are found in lower eukaryotes. The HK/RR signal transduction system is distinct from serine/threonine and tyrosine phosphorylation in higher eukaryotes. Specific inhibitors against TCS systems work differently from conventional antibiotics, and developing them into new drugs that are effective against various drug-resistant bacteria may be possible. Furthermore, inhibitors of TCSs that control virulence factors may reduce virulence without killing the pathogenic bacteria. Previous TCS inhibitors targeting the kinase domain of the histidine kinase sensor suffered from poor selectivity. Recent TCS inhibitors, however, target the sensory domains of the sensors blocking the quorum sensing system, or target the essential response regulator. These new targets are introduced, together with several specific TCSs that have the potential to serve as effective drug targets.
\end{abstract}

Key words_ — two-component signal transduction system; antibacterial drug; antivirulent drug

\section{1.はじめに}

微生物は地球上で最も環境に適応して変化する生 物である．特に細菌は，水河や海底の熱水噴出口の ような動物や植物が生き残ることができないような 環境でもみることができる。 それらは地球上に出現 して以来, 環境変化に適応するための機能を進化さ せてきた。 中でも, その様々な環境変化に適切に対 応するため，二成分情報伝達システム（TCS）とい うヒトを含む哺乳類には存在しないシステムを進化 させた，典型的な TCS は, 環境シグナルに応答し て自己リン酸化するセンサーキナーゼ（ヒスチジン キナーゼ，HK）とリン酸化された HK と相互作用 するレスポンスレギュレーター（RR）から構成さ れている。保存されたヒスチジン残基がリン酸化さ

$a$ 近畿大学大学院農学研究科バイオサイエンス専攻 (下631-8505 奈良市中町 3327-204), ${ }^{b}$ (公財) 微生物化 学研究会微生物化学研究所（广141-0021 東京都品川区 上大崎 3-14-23)

*e-mail: utsumi@nara.kindai.ac.jp

本総説は, 日本薬学会第 131 年会シンポジウム S05 で 発表したものを中心に記述したものである.
れた HK は，RR のアスパラギン酸残基へとリン酸 基を転移させる. リン酸化された RR は制御下遺伝 子の上流に結合し，それらの発現を調節する。ま た，リン酸化された RR は HK によって脱リン酸化 されることもある. 細胞中の RR のリン酸化状態 は，リン酸化と脱リン酸化のバランスによって決定 し，またその状態により遺伝子発現を制御している [Figs. 1(a) and (b)]. ${ }^{1)}$

様々な異なる環境変化に適応するため, 細菌は複 数の TCS を有している。 それぞれの TCS が $\mathrm{pH}$, 栄養状態, 酸化還元, 浸透圧, クオラムシグナルや 抗生物質のような特定の環境シグナルに応答する. またさらに，より多くの環境変化により敏感に応答 するため, 情報は複雑な情報伝達ネットワーク間の クロストークによって他の TCS にも伝えられ る. ${ }^{2,3)}$ いくつかの TCS は細胞増殖, 病原性, バイ オフィルム, クオラムセンシングなどに係わる遺伝 子クラスターを制御している. 従来の抗生物質は必 須な機能を担うタンパク質を直接標的としてい る. ${ }^{4)}$ 一方，TCS はそのような機能を担うタンパク 


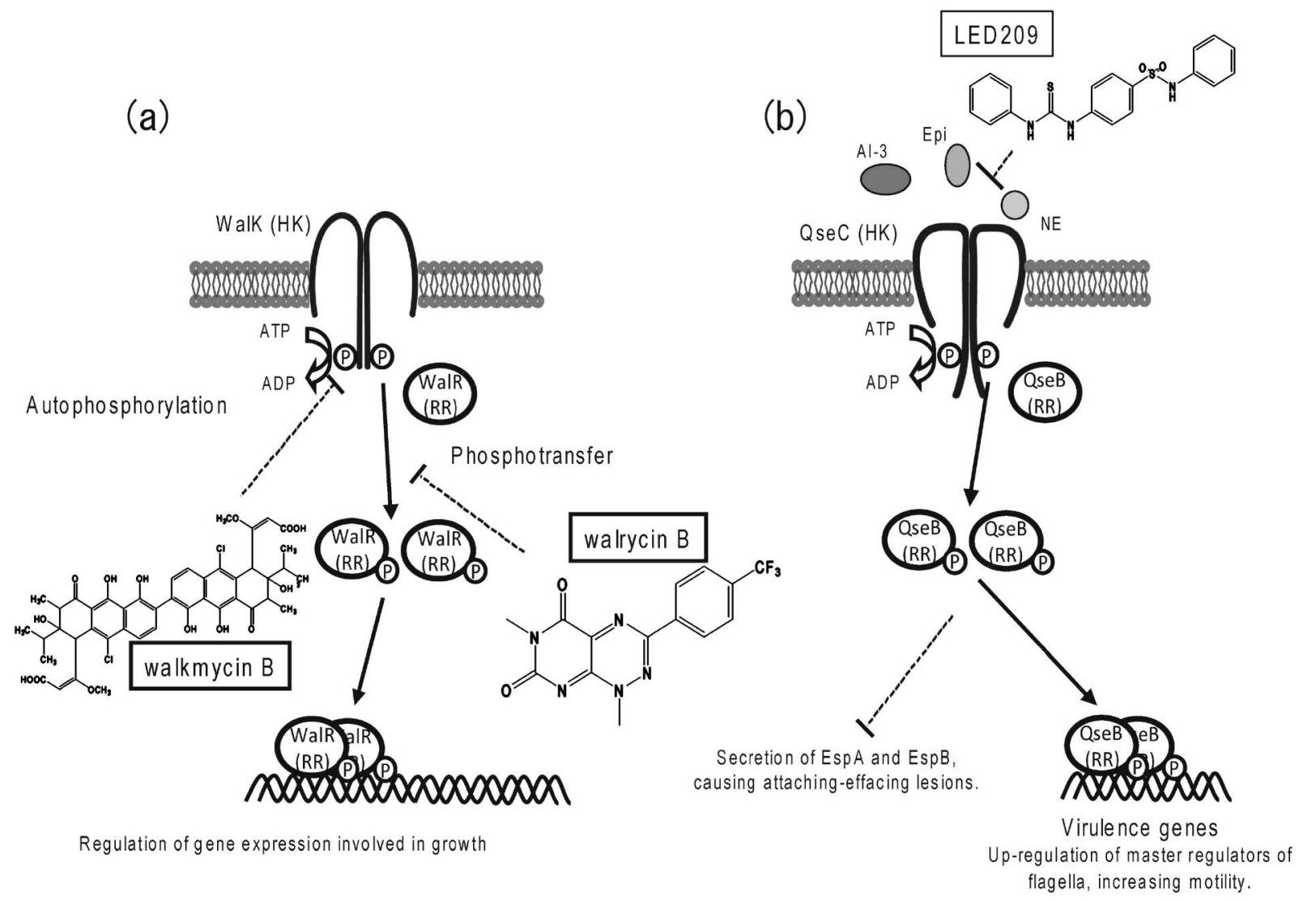

Fig. 1. Two-component Signal Transduction as Potential Drug Targets in Pathogenic Bacteria

(A) Inhibitors targeting the essential TCS, WalK/WalR. Walkmycin B inhibits autophosphorylation of WalK. Walrycin interacts with WalR and inhibits phosphotransfer from WalK. (B) QseC/QseB TCS and its inhibitor. AI-3; auto-inducer 3, Epi: epinephrine, NE: norepinephrine LED209 (N-phenyl-4- [ [ (phenylamino) thioxomethyl] amino] -benzenesulfonamide) blocks QseC autophosphorylation by inhibiting the binding of AI-3, Epi and NE.

質の遺伝子発現を制御しているので，その TCS 阻 害剂は既存の抗生物質とは異なり, 様々な薬剂耐性 菌に対しても効果のある新しい抗生物質, 農薬へ発 展する可能性がある. 増殖に必須な遺伝子発現を制 御する TCS を標的とする薬剤は, メチシリン耐性 黄色ブドウ球菌（Methicillin-resistant Staphylococcus aureus, MRSA）やバンコマイシン耐性腸球菌 (Vancomycin-resistant Enterococcus, VRE) のよう な多剂耐性菌に対しても抗菌性を示す［Fig. 1 (a) ]. ${ }^{5-8)}$ 一方, バイオフィルム形成やクオラムセ ンシングのような病原性を調節する TCS の阻害剤 は, 病原菌を殺すことなく病原性遺伝子の発現を制 御し，病原性を抑制することが可能である [Fig. 1(b)]. ${ }^{9-11)}$ 本総説では最初に細菌の細胞増殖に必須 な遺伝子を制御する TCS とその阻害剤を，ついで 増殖には関与しないが, 病原性遺伝子の発現を制御 する TCS とその阻害剤について紹介する.

\section{2. 新規抗菌剤の標的としての TCS}

2-1. WalK/WalR TCS WalK/WalR, ${ }^{12-18)} \mathrm{YhcS}$
/YhcR, ${ }^{19)}$ HP165/HP166, ${ }^{20)}$ MtrB/MtrA ${ }^{21) ~(そ れ そ ゙ ~}$ れ前者が HK，後者が RR を示す）はヒトに対する 病原菌の増殖に必須な遺伝子の発現を制御する TCS である (Table 1)。特に WalK/WalR は Bacillus subtilis, Staphylococcus aureus, Enterococcus faecalis, Listeria monocytogenes, Streptococcus mutans, Streptococcus pyogenes ${ }^{22)}$ などのグラム陽性菌 の細胞分裂や増殖に関与する遺伝子の発現を制御し ている [Fig. 1(a)]. WalK/WalR システムは最初, 機能が未知のために, YycG/YycF, VicK/VicR, $\mathrm{MicA} / \mathrm{MicB}$ 等と呼ばれていたが，近年の研究によ りこの TCS が細胞壁の代謝に重要な役割を担って いることが明らかとなり, WalK (HK), WalR （RR）と統一的に呼ばれるようになつた。 ${ }^{23)}$ 本章で は，筆者らが開発した，WalK 阻害剤 (walkmycin), WalR 阻害剂（walrycin）について紹介する.

2-2. walkmycin 最初に WalR の変異株 （CNM2000）が野生株と比較して, WalK/WalR 情 報伝達の各過程に特異的に作用する阻害剂に対して 
Table 1. TCS as Potential Drug Targets

\begin{tabular}{|c|c|c|c|c|c|}
\hline TCS（HK/RR） & Bacterium & Function & Regulated gene & Disease & Ref. \\
\hline \multicolumn{6}{|l|}{ Essential TCS } \\
\hline \multirow[t]{7}{*}{ WalK/WalR* } & S. aureus & Cell wall metabolism & isaA, ssaA, lytM & Opportunistic infection & 12 \\
\hline & S. pneumoniae & Cell wall metabolism & $\begin{array}{l}p c s B, \text { lyt } N, \text { fabK, } \\
p s p A, \operatorname{pia} B C D A\end{array}$ & Pneumoniae & 13 \\
\hline & S. mutans & Biofilm formation & $g t f B C D, f t f, g d p B$ & Caries & 14 \\
\hline & S. pyogenes & Cell wall metabolism & Unknown & Necrotizing fasciitis & 15 \\
\hline & S. epidermidis & Cell wall metabolism & Unknown & Opportunistic infection & 16 \\
\hline & L. monocytogenes & Unknown & Unknown & Listeriosis & 17 \\
\hline & E. faecalis & Unknown & Unknown & $\begin{array}{l}\text { Urinary tract infection } \\
\text { Bacterial endocarditis }\end{array}$ & 18 \\
\hline YhcS/YhcR & S. aureus & Unknown & Unknown & Opportunistic infection & 19 \\
\hline HP165/HP166 & H. pylori & Unknown & Unknown & Chronic gastritis & 20,47 \\
\hline $\mathrm{MtrB} / \mathrm{Mtr} \mathrm{A}$ & M. tuberculosis & Unknown & $d n a A$ & Tuberculosis & 21,48 \\
\hline \multicolumn{6}{|c|}{ Non-Essential TCS } \\
\hline \multirow[t]{4}{*}{ QseC/QseB } & EHEC & Quorum sensing & & Bloody diarrhea, HUS & 11,32 \\
\hline & & Regulation of the flagellar regulon & $f h D C$ & & \\
\hline & & Regulation of the LEE gene & ler & & \\
\hline & & Shiga toxin & stx & & \\
\hline AgrC/AgrA & S. aureus & Adhesion, Invasive factor & RNAIII & Opportunistic infection & 9,33 \\
\hline FsrC/FsrA & E. faecalis & Protease & gelE, sprE & Opportunistic infection & 40 \\
\hline $\mathrm{GacS} / \mathrm{GacA}$ & P. aeruginosa & $\begin{array}{l}\text { Lipase, Elastase, Biofilm, Virulence } \\
\text { Virulence, Cationic antimicrobial }\end{array}$ & $r s m Y, r s m Z$ & Opportunistic infection & 29,41 \\
\hline PhoQ/PhoP & S. enterica & Peptide resistance & $u g d, p b g D$ & Diarrhea & 45,46 \\
\hline
\end{tabular}

S. aureus: Staphylococcus aureus; S. pneumoniae: Streptococcus pneumoniae; S. mutans: Streptococcus mutans; S. pyogenes: Streptococcus pyogenes; S. epidermidis: Staphylococcus epidermidis; L. monocytogenes: Listeria monocytogene; H. pylori: Helicobactor pylori; M. tuberculosis: Mycobacterium tuberculosis. EHEC: Enterhemorrhagic Esherichia coli; E. faecalis: Enterococcus faecalis; P. aeruginosa: Pseudomonas aeruginosa; S. enterica: Salmonella enterica. ${ }^{*}$ also known as $\mathrm{YycG} / \mathrm{YycF}$, VicK/VicR, MicA/MicB.

高感受性を示す性質を利用したスクリーニング方法 （Differential growth assay）が確立された［Fig. 2(a) ]. ${ }^{24)}$ 次に, この方法を用いて, 放線菌の培養 抽出物 1368 検体のスクリーニングを実施した。土 猿より分離した一放線菌, Streptomyces sp. MK632 -100F11 株の培養抽出物から, シリカゲルカラムク ロマトグラフィー及び HPLC により 3 つの抗菌性 化合物を単離した [Fig. 2(b)]. 3 つの化合物につ いての構造解析を行つた結果, di-anthracenone 骨 格を持つ化合物であることが判明し，walkmycin $\mathrm{A}, \mathrm{B}, \mathrm{C}$ とした。主成分 walkmycin B $\left[\mathrm{C}_{44} \mathrm{H}_{44} \mathrm{Cl}_{2}\right.$ $\mathrm{O}_{14}$, Fig. 1(a)] のB. subtilis とS. aureus に対する 最小生育阻止濃度 (minimum inhibitory concentration，MIC）は，それぞれ， $0.39 \mu \mathrm{g} / \mathrm{mL}$ と $0.20 \mu \mathrm{g} /$ $\mathrm{mL}$ であった。また，B. subtilis と S. aureus の WalK 自己リン酸化活性に対する $50 \%$ 阻害濃度 $\left(\mathrm{IC}_{50}\right)$ は，それぞれ， $1.6 \mu \mathrm{M} ， 5.7 \mu \mathrm{M}$ であった. B. subtilis の WalK と walkmycin B 間の親和性を調
ベるために表面プラズモン共鳴法による解析を行つ た結果, 解離定数 $K_{\mathrm{d}}$ は, $7.63 \mu \mathrm{M}$ であった. MRSA, VRE に対する walkmycin A, B, C の抗菌評価にお いては, walkmycin A, B, C は MRSA, VRE に対 して, MIC (MRSA, 0.125-0.5 $\mu \mathrm{g} / \mathrm{mL}$; VRE, 1-8 $\mu \mathrm{g}$ /mL) を示した [Fig. 1(a)]. 7) これらの結果より, walkmycin は WalK の特定部位に作用して，ヒスチ ジンキナーゼ活性を阻害する最初の新規な抗生物質 と同定された. ${ }^{25,26)}$

2-3. walrycin B WalR タンパク質に対する 分子標的剂の開発を実施するために，WalR の立体 構造を X 線結晶構造解析法により決定した。 WalR タンパク質が $\mathrm{N}$ 末端ドメインと $\mathrm{C}$ 末端ドメイン構 造を有することを明らかにするとともに，WalK/ WalR 情報伝達機構の構造生物学的研究を行った. 最初に DNA 結合ドメイン（WalR-C）の結晶化を 行い, $\mathrm{X}$ 線結晶構造解析法によって立体構造決定 を行った。 WalR-Cは，典型的なレスポンスレギュ 
(a)

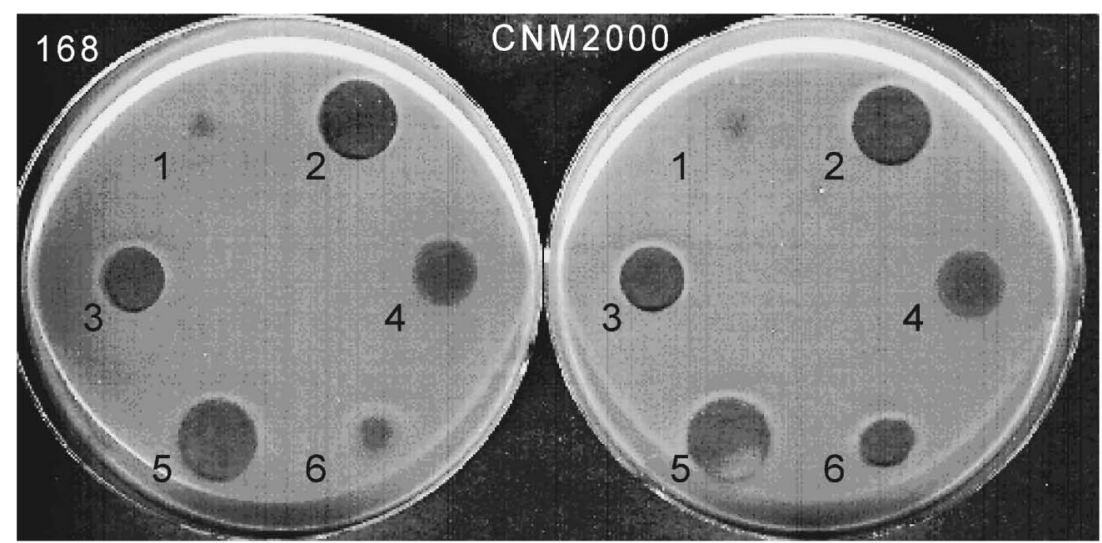

(b)
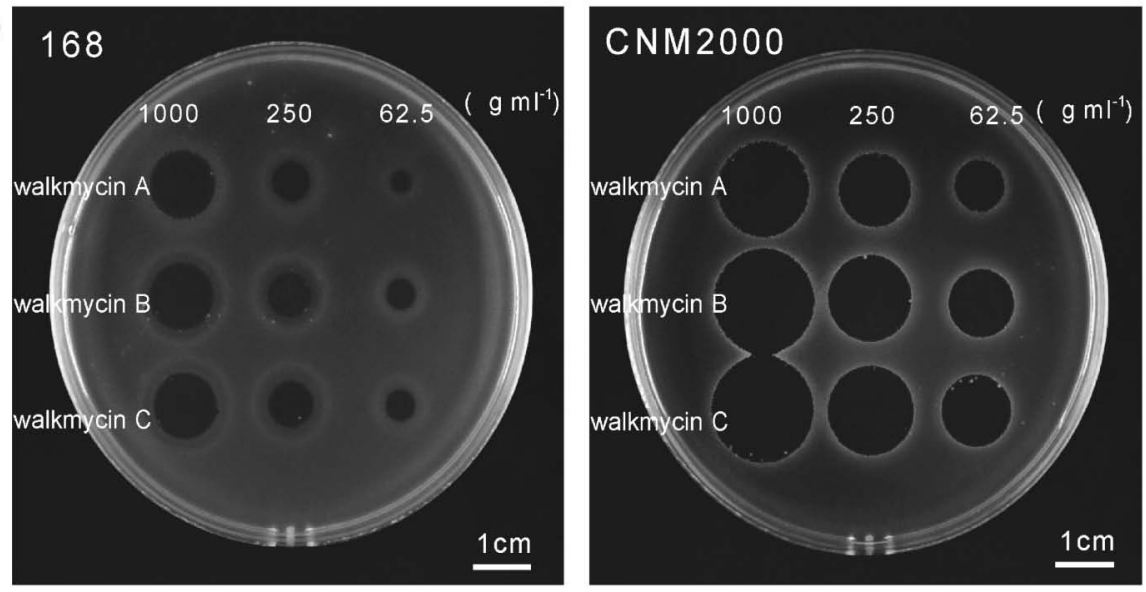

Fig. 2. Sensitivity of B. subtilis 168 and CNM2000 to Antibacterial Agents

(A) $1 \mu \mathrm{L}$ of antibacterial agents $\left(50 \mu \mathrm{gmL}^{-1}\right)$ were spotted on agar plates containing B. subtilis 168 (left) or CNM2000 (right): Cefazolin (1), Amikacin (2), Vancomycin (3), Erythromycin (4), Ofloxacin (5), NH127 (6). NH127 is a nonspecific HK inhibitor. (B) $1 \mu$ L of walkmycin A, B, and C (1000, $250,62.5$ $\mu \mathrm{gmL}^{-1}$ ) were spotted on agar plates containing B. subtilis 168 (left) or CNM2000 (right) with differential growth assay. ${ }^{24}$ )

レーターである OmpR/PhoB ファミリーに属し, DNA 結合タンパク質の特徵的な構造を示した. ${ }^{27)}$ また，WalR-C と標的 DNA との複合体モデルから， DNA 結合に係わる WalR のアミノ酸残基が予測さ れ，これらのアミノ酸への変異導入を行った WalR のゲルシフト法解析により, DNA 結合能の低下が みられたことから，DNA 認識に係わるアミノ酸を 立体モデルから明らかにした. 次に, WalR の二量 体形成ドメイン（WalR-N）の結晶化を行い，X線 結晶構造解析法によって立体構造決定を行った。 WalR-N は, 活性に重要な二量体（ $\alpha 4-\beta 5-\alpha 5)$ を結 晶構造中で形成しており, WalR タンパク質の制御 機構として二量体形成することを結晶構造から証明 した. ${ }^{28)}$ 一般に RR は二量体の状態で制御下遺伝子 の制御領域に結合することが知られていることから,

WalR は二量体として増殖に必須な標的遺伝子の制 御領域に存在する反復配列 $\left[5^{\prime}-\mathrm{TGT}(\mathrm{A} / \mathrm{T}) \mathrm{A}(\mathrm{A} / \mathrm{T} /\right.$
C) -N5-TGT (A/T) A (A/T/C) -3'] に結合すること が明らかにされた（Fig. 3).

このように WalR の二量体化が黄色ブドウ球菌の 増殖に必須であると考えられたので, WalR の二量 体化を阻害する化合物を選択的に単離するハイス ループットなスクリーニング手法（HD-WalR）を 開発した。 HD-WalR 法を用いて化合物ライブラ リーのハイスループットスクリーニングを実施した 結果, walrycin Bが単離された [Fig. 1(a) ]. ${ }^{8)}$ walrycin B の B. subtilis と S. aureus に対する MIC は，それぞれ $0.78 \mu \mathrm{g} / \mathrm{mL} ， 3.13 \mu \mathrm{g} / \mathrm{mL}$ であり， MRSA とVRE に対する MIC は，それぞれ $4 \mu \mathrm{g} /$ $\mathrm{mL}, 8 \mu \mathrm{g} / \mathrm{mL}$ であった。 また, in vitroにおいて リン酸化された WalKから WalR に対するリン酸基 転移を阻害するか検討したところ, walrycin B 濃度 依存的に阻害が確認された。 さらに, 作用解析を行 ったところ，B. subtilis とS. aureus ともに，walry- 


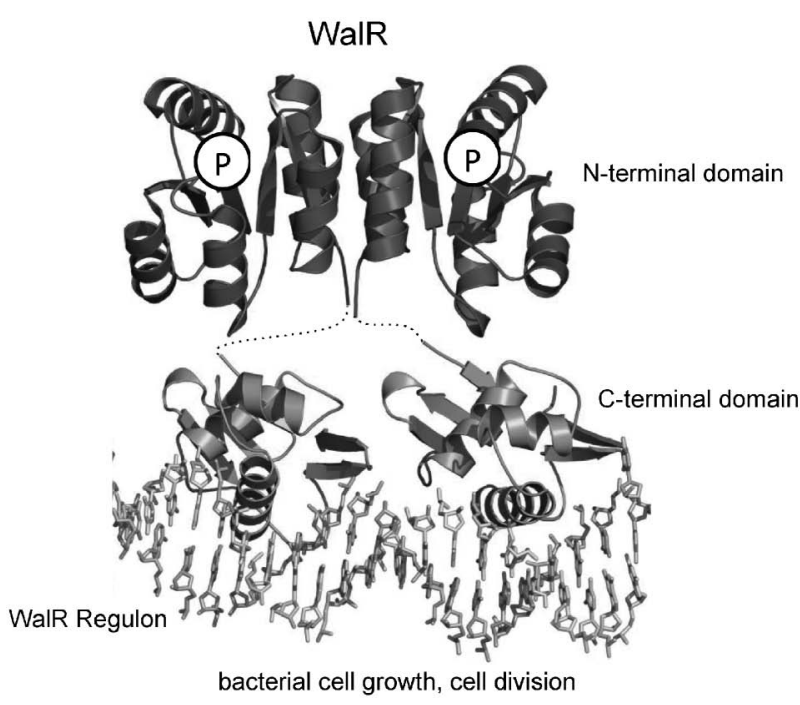

Fig. 3. DNA Binding Model of Phosphorylated WalR

cin B に対して，過剩発現株で 2-4 倍の耐性化が確 認された. 次に walrycin B のB. subtilis と S. aureus の細胞形態に及ぼす効果を調べた結果，walrycin B は B. subtilis の細胞分裂を阻害し，伸張したフィラ メント細胞を出現させた。 さらに，walrycin Bによ る WalR 制御遺伝子群の発現に与える影響について 検討した。 その結果，枯草菌において WalR によつ て正の制御を受ける 3 つの遺伝子群, $y d j M$ や $y o c H, y v c E$ は walrycin B 添加 5 分後に発現量の低 下が確認され，負の制御を受ける遺伝子群 yoeB yjeA においては発現量の増大が確認された。同様 のことが，S. aureus の WalR 制御遺伝子 isa $A$ と ssa A で確認された。これらより， walrycin B は WalR に直接作用して，その転写制御機能を阻害し ていることが明らかになった。

以上の結果より，筆者らは MRSA やVRE に対 しても有効な WalK 阻害剂 walkmycin B と WalR 阻害剂 walrycin B を単離することに成功し，WalK， WalR が MRSA, VREの新規抗生物質開発のため の標的として有望であることを示した.

\section{3. 病原性を制御する TCS}

病原菌の病原性因子は，宿主への侵入に関与する プロテアーゼやリパーゼ，毒素の生産や分泌等が含 まれる。 もう 1 つの重要な因子は宿主へ到達するた めの運動性, 宿主への付着, コロニー形成, 環境適 応に係わる因子である。病原菌は，宿主へ侵入する ときの $\mathrm{pH}$ や浸透圧の変化，あるいは抗菌ペプチド のような宿主からの抵抗などの環境変化に適応して
いくために，TCSによって病原性遺伝子の発現の 調節が行われる。例えば，様々な環境に生息する Pseudomonas aeruginosa は 64 個の HK と 72 個の RR がある。これらの TCS のうち，19 個の TCS は 病原性や抗生物質耐性に関与する. ${ }^{29)}$ グラム陽性菌 のS. pneumoniae も 13 個の TCS のうち 10 個が病 原性に関与する。本章は抗病原性薬剤の標的となり 得る 5 個の TCS の分子メカニズムについて言及す る (Table 1).

3-1. QseC/QseB 腸管出血性大腸菌（Enterohemorrhagic Escherichia coli, EHEC) O157 : H7 の 病原性遺伝子 (locus of enterocyte effacement: LEE) の発現は細胞密度が上昇したとき，EHECによる オートインデューサー3（AI-3）の分泌とともに急 速に誘導される (Quorum Sensing, QS). ${ }^{30)}$ さらに, LEE1 遺伝子の発現はヒトのホルモンであるエピネ フリン, ノルエピネフリンの添加によっても誘導さ れる. ${ }^{31)} \mathrm{QseC} / \mathrm{QseB}$ は AI-3，エピネフリンとノル エピネフリン等のシグナル分子に応答する TCS で ある。つまり，これらのシグナル分子はセンサーで ある $\mathrm{QseC}(\mathrm{HK})$ に直接作用し， $\mathrm{QseC}$ の自己リン 酸化を促進する。リン酸化された QseC は QseB （RR）と相互作用し，リン酸基を QseB に転移させ る。リン酸化された QseB は EHEC の病原性遺伝 子のプロモーターに結合し，それらの発現を誘導す る。 QseC/QseB は生存に必須な遺伝子を制御して いないので，QseC/QseB の阻害剂は EHEC 細胞を 殺すことなしに病原性遺伝子の発現のみを抑制する ことができる [Fig. 1(b)].

QseC の活性化を阻害する化合物を探索するため, EHEC の Lee1-lacZレポーター株を用いたハイス ループットスクリーニングが 150000 化合物の中か ら行われた. ${ }^{11)}$ その結果発見された化合物 LED209 は AI-3，エピネフリン，ノルエピネフリンが QseC に結合することを阻害する。つまり LED209 は QseCの自己リン酸化を阻害するのと同時に, EHEC の病原性遺伝子の $L E E 1, f h D C$ と stx $2 A$ を 抑制する。また，LED209 は EHEC の病原性を in vitro と in vivo の両方において抑制するが，増殖は 阻害しない. QseCのホモログは少なくとも 25 種 類のヒトや植物の病原菌に存在するため, $\mathrm{QseC} の$ 阻害剂は様々な病原菌の抗病原性薬剤となることが 期待される. ${ }^{32}$ 
3-2. AgrC/AgrA Staphylococcus aureus は autoinducing cyclic thiolactone peptides (AIPs) を 生産し, 細胞外に分泌する.S. aureus の病原性は AIPs と AgrC/AgrA TCS（agr QS システム）によ つて制御される. ${ }^{33)} a g r$ QS システムの下で，シグ ナル AIPs は最初に生産される AgrD が細胞膜を通 過するときに生産され，細胞膜上に存在する AgrB によって修飾される，修飾された AIPs がセンサー $\operatorname{AgrC}$ に作用すると， $\operatorname{AgrC}$ がリン酸化され AgrA にリン酸基を転移させる. ${ }^{34)}$ リン酸化された AgrA は RNA III 遺伝子と a grB の間の領域に直接結合し, RNA III の転写を促進する。 RNA III は付着性因 子の発現を負に制御する一方で，プロテアーゼや分 泌される毒素, リパーゼのような侵入性の病原性因 子の発現を正に制御する. ${ }^{33)}$ 宿主の血清中に存在す る先天的な防御因子であり，リポプロテインの主要 な構造タンパク質であるアポリポプロテイン B は AIP1 を隔離することによって $a g r \mathrm{QS}$ システムを 阻害することが報告されている. ${ }^{35}$

3-3. FsrC / FsrA Enterococcus faecalis の 病 原性遺伝子であるゼラチナーゼ遺伝子 gelE (encoding a metalloprotease) と sprE (encoding a serine protease) ${ }^{36)}$ は同じオペロン上に位置し，ラクトン 環を持つ環状ペプチドで細胞外に分泌される GBAP (gelatinase biosynthesis activating pheromone）を濃度依存的に発現する。豆) GBAP の生産 と分泌は TCS である FsrC/FsrA によって正に制御 される。また，GBAP は FsrC/FsrA が $f_{s r B D C}$ と gelE-sprE の遺伝子発現を制御しゼラチナーゼとセ リンプロテアーゼを生産させ，病原性を引き起こさ せるきっかけを作る。そのため, FsrC/FsrA の阻 害剂は E. faecalis の病原性を抑制することが期待 される， $f_{s} r \mathrm{QS}$ の阻害剂を探索するため，ゼラチ ナーゼと GBAP の生産が抑制される化合物が放線 菌抽出物からスクリーニングされた. ${ }^{38)}$ ペプチド抗 生物質である Siamycin I はスクリーニングにより 選ばれた放線菌抽出物の上清より単離された。

Siamycin I は FsrC/FsrA を経る GBAP シグナリン グを阻害し， fsrBDC と gelE-sprE の転写を抑制す る.

3-4. GacS/GacA Pseudomonas aeruginosa の 病原性はセンサーヒスチジンキナーゼの GacS と RetS の相互作用によって決定される. ${ }^{39)} P$. aer- uginosa において GacS/GacA は small RNA をコー ドする $r s m Y$ と $r s m Z$ 遺伝子の転写を正に制御する. RsmY と RsmZ は RsmA (RNA-binding-protein) と相互作用し，アシルホモセリンラクトン，ピオシ アニン, リパーゼ, エラスターゼ，バイオフィルム 形成，運動性などの病原性因子を調節する. ${ }^{40)}$ また, Vibrio vulnificusにおいても GacA は small RNA (csrB1, csrB2, csrB3) の転写を正に制御しており， $g a c A$ の欠損株においてそれらの転写は減少する. 結果として, $V$. vulnificus の GacA 欠損株は細胞毒 性，プロテアーゼ活性，夾膜多糖類や鉄の取り込み のための能力が減少し，鉄の非存在下においては病 原性が低下する. ${ }^{41)} \mathrm{GacS} / \mathrm{GacA}$ システムは，哺乳 類に対する病原菌のみならず，昆虫や植物などに対 する病原菌においてもみられ，それらの病原性に関 与していることから $\mathrm{GacS} / \mathrm{GacA}$ システムは病原性 抑制剤の標的として魅力的であると考えられる。こ れまでのところ， GacS/GacA を標的とする薬剤の 報告はないが，今後期待される.

3-5. PhoQ/PhoP Salmonella enterica の TCS のうち, PhoQ/PhoP システムが病原性の主要な制 御を行っている。 センサーPhoQ は細胞外の $\mathrm{Mg}^{2+}$ の濃度を感知し， RR である PhoP を経て S. enteri$c a$ の約 3\%の遺伝子の発現を調節すると推定されて いる. ${ }^{42)} \mathrm{PhoQ} / \mathrm{PhoP}$ システムは上皮細胞への侵 入, 食細胞中での生存, 抗菌ペプチドに対する耐性 などの Salmonella の能力を制御していると考えら れる. ${ }^{43,44)} \mathrm{HK}$ は特徵的な ATP 結合ドメインの特 徵 (ATP-binding Bergerat fold) が GHL (gyrase, Hsp90, MutL) ファミリータンパク質と同様である ことから, ${ }^{45)} \mathrm{GHL}$ 阻害剤と PhoQ の触媒ドメイン との相互作用が NMR の化学シフト摂動法によって 解析された。阻害剂のうち，ラジコール（Hsp90 の阻害剂）が PhoQ の ATP 結合ポケットのアミノ 酸残基と特異的に結合し，相互作用していることが 結晶構造解析により明らかとされた。ラジコールは 比較的低いアフィニティーではあるが，PhoQ の自 己リン酸化活性を阻害した（1 mM のラジコールで $10 \%$ 阻害)。これは，GHL の阻害剂が HK 阻害剂 として開発するためのリード化合物として利用可能 であることを示しているが（この場合は PhoQ に 対してだけでなく，様々な HKに対する阻害剤で ある), ${ }^{46)} \mathrm{HK}$ に対する選択性を他の哺乳類の酵素 
の ATP 結合部位に対する選択性とを比較する必要 がある。

\section{4. まとめ}

このように，本誌で紹介された細菌情報伝達阻害 剤は，情報伝達システムを阻害し，その標的となる 遺伝子発現を制御することで，病原菌の病原性の抑 制並びに増殖阻害(死滅)させることが可能であり, 既知抗生物質に耐性な病原菌にも有効に作用する. また，その作用の特徵として，病原菌を殺さずにそ の疾病を治癒する効果が示されており，耐性菌の出 現頻度が極めて低く, 21 世紀の環境調和型薬剤と 位置づけられる。細菌情報伝達阻害剂研究は，今ま で踏み込まれていない未知の分野であり，20 世紀 代謝系阻害剂（既知抗生物質）が製薬産業の主要な 活力（黄金時代）であったように，21 世紀におけ る製薬産業の新しい起爆剂となることが期待される.

謝辞本稿をまとめるにあたり尽力頂きました, 近畿大学大学院農学研究科 岡本尚博士 (現, 遺伝 研)，江口陽子博士，土井章弘博士（現，理化学研 究所), 大阪大学産業科学研究所, 岡島俊英准教授 に感謝いたします，本総説における，WalK/WalR 阻害剂の開発研究は生研センター異分野融合支援事 業“環境調和を考慮した細菌情報伝達阻害型薬剤の 開発”, 科学技術振興機構研究成果展開事業 ASTEP 本格研究開発 起業挑戦タイプ(AS2123003G), 科研費基盤研究 A (20248012)，私立大学戦略的研 究基盤形成支援事業（S1101035）の助成で実施さ れた成果で, (公財) 微生物化学研究会, 微生物化学 研究所研究員の夕なさん, 近畿大学大学院農学研究 科バイオサイエンス専攻分子生物学研究室の院生, 研究員の協力の賜物です。ここに, 厚く御礼申し上 げます。

\section{REFERENCES}

1) Gao R., Stock A. M., Annu. Rev. Microbiol., 63, 133-154 (2009).

2) Eguchi Y., Utsumi R., Adv. Exp. Med. Bio., 631, 1-6 (2008) .

3) Mitrophanov A. Y., Groisman E. A., Genes Dev., 22, 2601-2611 (2008) .

4) Walsh C., “Antibiotics," ASM Press, Washington D.C., 2003.

5) Dubrac S., Msadek T., Adv. Exp. Med. Biol.,
631, 214-228 (2008).

6) Watanabe T., Okada A., Gotoh Y., Utsumi R., Adv. Exp. Med. Biol., 631, 229-236 (2008).

7) Okada A., Igarashi M., Okajima T., Kinoshita N., Umekita M., Sawa R., Inoue K., Watanabe T., Doi A., Martin A., Quinn J., Nishimura Y., Utsumi R., J. Antibiot. (Tokyo), 63, 89-94 (2010) .

8) Gotoh Y., Doi A., Furuta E., Dubrac S., Ishizaki Y., Okada M., Igarashi M., Misawa N., Yoshikawa H., Okajima T., Msadek T., Utsumi R., J. Antibiot. (Tokyo), 63, 127-134 (2010).

9) Cegelski L., Marshall G. R., Eldridge G. R., Hultgren S. J., Nat. Rev. Microbiol., 6, 17-27 (2008).

10) Dong Y. H., Wang L. H., Xu J. L., Zhang H. B., Zhang X. F., Zhang L. H., Nature, 411, 813-817 (2001).

11) Rasko D. A., Moreira, C. G., Li de R., Reading N. C., Ritchie J. M., Waldor M. K., Williams N., Taussig R., Wei S., Roth M., Hughes D. T., Huntley J. F., Fina M. W., Falck J. R., Sperandio V., Science, 321, 1078-1080 (2008).

12) Martin P. K., Li T., Sun D., Biek D. P., Schmid M. B., J. Bacteriol., 181, 3666-3673 (1999) .

13) Lange R., Wagner C., de Saizieu A., Flint N., Molnos J., Stieger M., Caspers P., Kamber M., Keck W., Amrein K. E., Gene, 237, 223234 (1999).

14) Senadheera M. D., Guggenheim B., Spatafora G. A., Huang Y. C., Choi J., Hung D. C., Treglown J. S., Goodman S. D., Ellen R. P., Cvitkovitch D. G., J. Bacteriol., 187, 40644076 (2005).

15) Liu M., Hanks T. S., Zhang J., McClure M. J., Siemsen D. W., Elser J. L., Quinn M. T., Lei B., Microbiology, 152, 967-978 (2006).

16) Qin Z., Zhang J., Xu B., Chen L., Wu Y., Yang X., Shen X., Molin S., Danchin A., Jiang H., Qu D., BMC Microbiol., 6, 96 (2006).

17) Kallipolitis B. H., Ingmer H., FEMS Microbiol. Lett., 204, 111-115 (2001).

18) Hancock L., Perego M., J. Bacteriol., 184, 5819-5825 (2002). 
19) Sun J., Zheng L., Landwehr C., Yang J., Ji Y., J. Bacteriol., 187, 7876-7880 (2005).

20) Beier D., Frank R., J. Bacteriol., 182, 20682076 (2000).

21) Zahrt T. C., Deretic V., J. Bacteriol., 182, 3832-3838 (2000).

22) Dubrac S., Bisicchia P., Devine K. M., Msadek T., Mol. Microbiol., 70, 1307-1322 (2008).

23) Dubrac S., Boneca I. G., Poupel O., Msadek T., J. Bacteriol., 189, 8257-8269 (2007) .

24) Okada A., Gotoh Y., Watanabe T., Furuta E., Yamamoto K., Utsumi R., Methods Enzymol., 422, 386-395 (2007).

25) Igarashi M., Eguchi Y., Umekita M., Watanabe T., Sawa R., Utsumi R., Abstracts of papers, the 50th Interscience Conference on Antimicrobial Agents and Chemotherapy (ICAAC), Boston, September 2010, F1-1617.

26) Eguchi Y., Kubo N., Matsunaga H., Igarashi M., Utsumi R., Antimicrob. Agents Chemother., 55, 1475-1484 (2011).

27) Okajima T., Doi A., Okada A., Gotoh Y., Tanizawa K., Utsumi R., FEBS Lett., 582, 3434-3438 (2008).

28) Doi A., Okajima T., Gotoh Y., Tanizawa K., Utsumi R., Biosci. Biotechnol. Biochem., 74, 1901-1907 (2010).

29) Gooderham W. J., Hancock R. E., FEMS Microbiol. Rev., 33, 279-294 (2009).

30) Sperandio V., Mellies J. L., Nguyen W., Shin S., Kaper J. B., Proc. Natl. Acad. Sci. USA, 96, 15196-15201 (1999).

31) Sperandio V., Torres A. G., Jarvis B., Nataro J. P., Kaper J. B., Proc. Natl. Acad. Sci. USA, 100, 8951-8956 (2003).

32) Njoroge J., Sperandio V., EMBO Mol. Med., 1, 201-210 (2009).

33) George E. A., Muir T. W., ChemBioChem, 8, 847-855 (2007).

34) Lina G., Jarraud S., Ji G., Greenland T., Pedraza A., Etienne J., Novick R. P., Van- denesch F., Mol. Microbiol., 28, 655-662 (1998).

35) Peterson M. M., Mack J. L., Hall P. R., Alsup A. A., Alexander S. M., Sully E. K., Sawires Y. S., Cheung A. L., Otto M., Gresham H. D., Cell Host Microbe, 4, 555-566 (2008).

36) Qin X., Singh K. V., Weinstock G. M., Murray B. E., Infect. Immun., 68, 2579-2586 (2000).

37) Nakayama J., Cao Y., Horii T., Sakuda S., Akkermans A. D., de Vos W. M., Nagasawa H., Mol. Microbiol., 41, 145-154 (2001).

38) Nakayama J., Tanaka E., Kariyama R., Nagata K., Nishiguchi K., Mitsuhata R., Uemura Y., Tanokura M., Kumon H., Sonomoto K., J. Bacteriol., 189, 1358-1365 (2007).

39) Goodman A. L., Merighi M., Hyodo M., Ventre I., Filloux A., Lory S., Genes Dev., 23, 249 -259 (2009).

40) Lapouge K., Schubert M., Allain F. H., Haas D., Mol. Microbiol., 67, 241-253 (2008).

41) Gauthier J. D., Jones M. K., Thiaville P., Joseph J. L., Swain R. A., Krediet C. J., Gulig P. A., Teplitski M., Wright A. C., Microbiology, 156, 3722-3733 (2010) .

42) Miller S. I., Mekalanos J. J., J. Bacteriol., 172, 2485-2490 (1990).

43) Fields P. I., Groisman E. A., Heffron F., Science, 243, 1059-1062 (1989).

44) Miller S. I., Kukral A. M., Mekalanos J. J., Proc. Natl. Acad. Sci. USA, 86, 5054-5058 (1989).

45) Dutta R., Inouye M., Trends Biochem. Sci., 25, 24-28 (2000).

46) Guarnieri M. T., Zhang L., Shen J., Zhao R., J. Mol. Biol., 379, 82-93 (2008) .

47) Dietz P., Gerlach G., Beier D., J. Bacteriol., 184, 350-362 (2002).

48) Fol M., Chauhan A., Nair N. K., Maloney E., Moomey M., Jagannath C., Madiraju M. V., Rajagopalan M., Mol. Microbiol., 60, 643657 (2006). 